\title{
The occurrence of Adrenocorticotropic hormone-independent Cushing's syndrome in a woman with the history of papillary thyroid carcinoma: a case report
}

\author{
Mashallah Tabatabaizadeh ${ }^{1 *}$, Sara Hasibi Taheri ${ }^{2}$, Mohammad Eydi ${ }^{3}$ and Mohammad Shayestehpour ${ }^{1}$
}

\begin{abstract}
Background: Thyroid papillary carcinoma is one of the most common endocrine tumors, and it accounts for $85 \%$ of thyroid tumors. Adrenocorticotropic hormone (ACTH)-independent Cushing's syndrome is a rare disease. In this case report, we discuss a very rare case of coexistence of papillary thyroid carcinoma and Cushing's syndrome with an adrenal origin.

Case presentation: The patient was a 33-year-old Iranian/Persian woman with a history of papillary thyroid carcinoma treated with iodine 131 three years ago. She presented with weight gain, amenorrhea, and mood disorders in the last six months. She was diagnosed with an ACTH-independent Cushing's syndrome due to benign adrenal adenoma and underwent laparoscopic adrenalectomy surgery. The symptoms of the syndrome were disappeared after the surgery.

Conclusions: ACTH-independent Cushing's syndrome due to adrenal tumor and papillary thyroid cancer occurs sporadically. The co-occurrence of two endocrine tumors with different origins is rare. It is recommended that the occurrence of other endocrine neoplasms be considered when an endocrine tumor is diagnosed.
\end{abstract}

Keywords: Cushing's syndrome, Adrenal adenoma, Papillary thyroid carcinoma (PTC)

\section{Introduction}

Endocrine tumors make up about $4 \%$ of the body's tumors. Thyroid papillary carcinoma is one of the most common endocrine tumors, and it accounts for $85 \%$ of thyroid tumors. Cushing's syndrome is a rare disease with a prevalence of $1-2$ cases per 100,000 people in the population. Only $10 \%$ of patients have Adrenocorticotropic hormone (ACTH)-independent Cushing's syndrome, and a majority of those are women. Exogenous Cushing is the most common cause of Cushing Syndrome.

*Correspondence: mashallahtabatabaizade@gmail.com

${ }^{1}$ Autoimmune Disease Research Center, Kashan University of Medical Sciences, Kashan, IR, Iran

Full list of author information is available at the end of the article
Adrenocortical adenoma, adrenocortical carcinoma, and adrenal micronodular hyperplasia can cause ACTHindependent Cushing's syndrome [1].

Cushing's syndrome is caused by chronic exposure of the body to glucocorticoids; therefore, the increase of cortisol level affects several physiological systems. The majority of clinical signs and symptoms observed in Cushing's syndrome are non-specific and include manifestations such as obesity, diabetes, hypertension, hirsutism, and depression. Cushing's diagnosis should be considered when multiple manifestations are found in the same patient, especially specific manifestations, including the fragility of the skin, accompanied by easy bruising, purple wide striae, and symptoms of proximal myopathy [1]. original author(s) and the source, provide a link to the Creative Commons licence, and indicate if changes were made. The images or other third party material in this article are included in the article's Creative Commons licence, unless indicated otherwise in a credit line to the material. If material is not included in the article's Creative Commons licence and your intended use is not permitted by statutory regulation or exceeds the permitted use, you will need to obtain permission directly from the copyright holder. To view a copy of this licence, visit http://creativecommons.org/licenses/by/4.0/. The Creative Commons Public Domain Dedication waiver (http://creativeco mmons.org/publicdomain/zero/1.0/) applies to the data made available in this article, unless otherwise stated in a credit line to the data. 
There are few case reports on the coexistence of thyroid papillary carcinoma and adrenal adenoma. In a case study reported in Israel, a 72-year-old man had a rare coexistence of papillary, medullary, follicular thyroid carcinoma, and Cushing's syndrome caused by the left adrenal adenoma [2]. In another case report in Turkey, a 40-year-old patient had both a rare adrenal mass and papillary thyroid carcinoma [3]. Tung et al. were reported the co-occurrence of bilateral papillary thyroid cancer (PTC) cancer with adrenal adenoma leading to Cushing's syndrome in a 41-year-old man diagnosed with Carney syndrome [4]. Carney complex is a hereditary multiple endocrine neoplasia syndrome characterized by spotty skin pigmentation and mucosal surfaces, cardiac and noncardiac myxomatous tumors, and multiple endocrine tumors. In this case report, we discuss a very rare case of coexistence of papillary thyroid carcinoma and Cushing's syndrome with an adrenal origin.

\section{Case presentation}

The patient was a 33-year-old Iranian/Persian woman with a history of bilateral multifocal papillary thyroid carcinoma and left-sided cervical lymphadenopathy. She underwent a total thyroidectomy and treated with iodine 131 at a dose of $150 \mathrm{ml} 3$ years ago. Subsequently, she gradually was developed weakness, lethargy, facial swelling (moon face), and abdominal obesity. The patient's weight was increased from 70 to $113 \mathrm{~kg}$ over 3 years, and nutrition counseling did not control her weight gain. The patient was referred to Shahid Beheshti Hospital in Kashan, Iran. She was completed a consent form. The patient did not have a family history of thyroid disease or a malignancy. She was living in Kashan and was not an addict or a smoker. The patient was taking Levothyroxine (100 $\mu \mathrm{g}$ daily), Sertraline (100 mg bidaily), Propranolol (20 mg bidaily), and Respridone (1 mg bidaily). The patient did not have a history of steroid use. The patient experienced irregular menstrual cycles with intervals of 90 days and the duration of each cycle equal to 4 days. She had low-volume bleeding, and over time, the intervals between her menstrual cycles were increased. Eventually, the menstrual cycle was interrupted, and the patient was developed secondary amenorrhea. She was experienced mood swings, depression, and aggression during this period that did not improve despite treatment. Her blood pressure was 150/50, and her Body mass index (BMI) was 42. Hirsutism was observed on her face, breast, and around the navel. Purple striae on the abdomen, dryness all over the skin, multiple ecchymoses on the leg (easy bruising), a and muscle strength of $4 / 5$ on both lower limbs were evident.

Firstly, laboratory tests, including Thyroid-stimulating Hormone (TSH), Follicle-stimulating Hormone (FSH), Luteinizing Hormone (LH), Prolactin, Estradiol, urinefree cortisol (24 hours), and overnight dexamethasone were requested for the patient (Table 1). The screening

Table 1 The result of laboratory tests in a woman with the history of papillary thyroid carcinoma and ACTH-independent Cushing's syndrome

\begin{tabular}{lll}
\hline Reference range & Result & Test \\
\hline $0.4-4.0 \mathrm{mlU} / \mathrm{L}$ & $0.2 \mathrm{mlU} / \mathrm{L}$ & $\mathrm{TSH}$ \\
$<33 \mathrm{ng} / \mathrm{ml}$ & $0.04 \mathrm{ng} / \mathrm{ml}$ & $\mathrm{Tg}$ \\
$1.2-12.5 \mathrm{IU} / \mathrm{L}$ & $0.5 \mathrm{IU} / \mathrm{L}$ & $\mathrm{FSH}$ \\
$3.7-7.8 \mathrm{IU} / \mathrm{L}$ & $0.1 \mathrm{U} / \mathrm{L}$ & $\mathrm{LH}$ \\
$30-400 \mathrm{pg} / \mathrm{ml}$ & $<5 \mathrm{pg} / \mathrm{ml}$ & Estradiol \\
$<14 \mathrm{ng} / \mathrm{mL}$ & $16.77 \mathrm{ng} / \mathrm{ml}$ & Prolactin \\
$800-2000 \mathrm{ml} / \mathrm{day}$ & $1590 \mathrm{ml} / \mathrm{day}$ & Urine volume (24hrs) \\
$800-1800 \mathrm{mg} / 24$ hours & $610 \mathrm{mg} / 24 \mathrm{hours}$ & Urine creatinine (24hrs) \\
$<20 \mu \mathrm{g} / 24 \mathrm{hour}$ & $446 \mu \mathrm{gg} / 24 \mathrm{hours}$ & Urine Free cortisol (24hrs) \\
$<2 \mu \mathrm{g} / \mathrm{dL}$ & $12.42 \mathrm{\mu g} / \mathrm{dL} 342.792 \mathrm{nmol} / \mathrm{L}$ & Overnight Dexamethasone test Cortisol (8 AM) \\
$<5 \mu \mathrm{g} / \mathrm{dL}$ & $16.78 \mathrm{\mu g} / \mathrm{dL}=463.128 \mathrm{nmol} / \mathrm{L}$ & Low dose Dexamethasone test Cortisol (8 AM) \\
$10-60 \mathrm{pg} / \mathrm{ml}$ & $1.2 \mathrm{pg} / \mathrm{ml}$ & ACTH \\
$70-100 \mathrm{mg} / \mathrm{dL}$ & $143 \mathrm{mg} / \mathrm{dL}$ & FBS \\
$<150 \mathrm{mg} / \mathrm{dL}$ & $256 \mathrm{mg} / \mathrm{dL}$ & Triglyceride \\
$<200 \mathrm{mg} / \mathrm{dL}$ & $295 \mathrm{mg} / \mathrm{dL}$ & Cholesterol \\
$85-125 \mathrm{mg} / \mathrm{dL}$ & $125 \mathrm{mg} / \mathrm{dL}$ & LDL \\
$40-80 \mathrm{mg} / \mathrm{dL}$ & $37 \mathrm{mg} / \mathrm{dL}$ & HDL \\
$136-145 \mathrm{mmol} / \mathrm{L}$ & $138 \mathrm{mmol} / \mathrm{L}$ & Na \\
$3.5-5 \mathrm{mmol} / \mathrm{L}$ & $4.07 \mathrm{mmol} / \mathrm{L}$ & $\mathrm{K}$ \\
\hline
\end{tabular}

TSH: Thyroid-stimulating Hormone, Tg: Thyroglobulin, FSH: Follicle-stimulating Hormone, LH: Luteinizing Hormone, ACTH: Adrenocorticotropic hormone, FBS: Fasting Blood Sugar, LDL: Low-Density Lipoprotein, HDL: High-Density Lipoprotein, Na: sodium, K: potassium 
tests of Cushing's syndrome were positive; therefore, the low-dose dexamethasone test was performed to confirm the diagnosis. The patient was treated for two days with $0.5 \mathrm{mg}$ dexamethasone every 6 hours, and the cortisol level (8 AM) was above $50 \mathrm{nmol} / \mathrm{L}$ [4].

The cortisol level was $463 \mathrm{nmol} / \mathrm{L}$; therefore, Cushing's syndrome was proposed for the patient. The ACTH level was measured to differentiate Cushing's syndrome from Cushing's disease. It was below $5 \mathrm{pg} / \mathrm{ml}$, and the disease was considered as ACTH-independent Cushing's syndrome. An adrenal mass was observed in a computerized tomography (CT) scan of the adrenal gland (Fig 1). The patient underwent laparoscopic right adrenalectomy and was removed a mass with $3.5 \mathrm{~cm}$ in diameter and weighing $18 \mathrm{~g}$. Pathologic evaluation was suggested the benign adrenal adenoma. The mass was a fatty tissue without necrosis and hemorrhage. During 6 days after surgery, the patient was treated with an injection of $100 \mathrm{mg}$ daily hydrocortisone. She was treated with oral prednisolone (5 mg daily) after discharge.

After 4 months, most of the symptoms of Cushing's syndrome, including weight gain, menstrual irregularities, hirsutism, and abdominal striae were partially cured. The patient's blood pressure, electrolytes, and TSH levels were normal, while she was receiving prednisolone and levothyroxine 100 micrograms per day. No mass was observed on a CT scan of the patient's abdomen after three months; therefore, the surgery was successful.

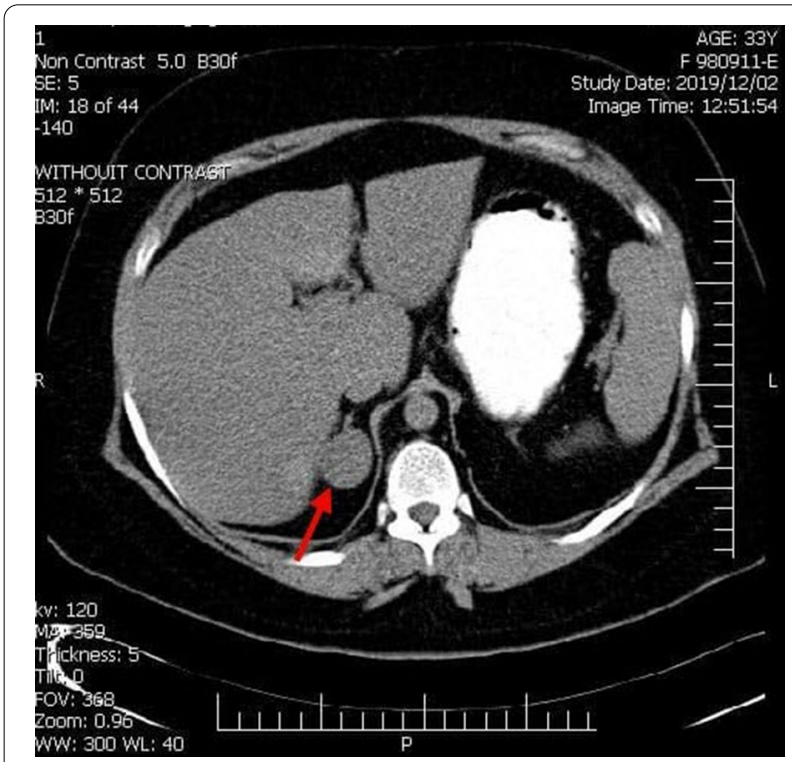

Fig. 1 Spiral computed tomography of the abdomen using injection contrast: arrow shows a $3.5 \mathrm{~cm}$ diameter mass with a regular margin and significant hemogenic density in the right adrenal gland

\section{Discussion}

Cushing's syndrome indicates chronic exposure of the body to glucocorticoids for any reason. The disorder can be ACTH-dependent (pituitary adenoma, non-pituitary ACTH-secreting tumor) and ACTH-independent (adrenal adenoma or carcinoma, adrenal hyperplasia).

Cushing's syndrome is generally one of the rare diseases, and its prevalence is $1-2$ cases per 100,000 population. Only $10 \%$ of patients have ACTH-independent Cushing's, and a majority of those are women [1].

The coexistence of PTC bilateral multi-focal cancer and $\mathrm{ACTH}$-independent Cushing's syndrome with the origin of unilateral adrenal adenoma has not been reported in the literature. In a study conducted in Imam Khomeini Hospital, Tehran, Iran, none of the 253 cases with Cushing's syndrome had a history of PTC [5].

In the present case report, we found a 33-year-old woman with a history of papillary thyroid cancer and symptoms of Cushing's, abdominal obesity, and amenorrhea, who had an adrenal adenoma. Two weeks after laparoscopic adrenalectomy surgery, the level of 24-hour urinary cortisol significantly was decreased to the normal level. After 4 months, most of the symptoms of Cushing's syndrome were partially cured. The result of the bone scan was normal; therefore, it was ensured that recurrence or metastasis of papillary carcinoma did not occur. The co-occurrence of two endocrine tumors was not related to each other and it is a rare event.

\section{Conclusion}

ACTH-independent Cushing's syndrome due to adrenal tumor and papillary thyroid cancer occur sporadically. The co-occurrence of two endocrine tumors with different origins is rare. It is recommended that the occurrence of other endocrine neoplasms be considered when an endocrine tumor is diagnosed.

\section{Abbreviations \\ ACTH: Adrenocorticotropic hormone; PTC: Papillary thyroid carcinoma.}

\section{Acknowledgements}

The authors would like to acknowledge the research deputy at Kashan University of Medical Sciences for their support.

\section{Authors' contributions}

MT, SHT and ME conceived the idea and study design; MSH analyzed the data and wrote the manuscript. All authors read and approved the final manuscript.

\section{Funding}

This study was funded by Kashan University of Medical Sciences.

\section{Availability of data and materials}

No additional file is available for this study; all the data are included in the manuscript. 


\section{Ethics approval and consent to participate}

This study was approved by Ethics Committee of Kashan University of Medical Sciences. The patient was assigned an informed written consent form.

\section{Consent for publication}

Written informed consent was obtained from the patient for publication of this case report and any accompanying images. A copy of the written consent is available for review by the Editor-in-Chief of this journal.

\section{Competing interests}

The authors declare that they have no competing interests.

\section{Author details}

${ }^{1}$ Autoimmune Disease Research Center, Kashan University of Medical Sciences, Kashan, IR, Iran. ${ }^{2}$ Department of Internal Medicine, Kashan University of Medical Sciences, Kashan, IR, Iran. ${ }^{3}$ Department of General Surgery, Kashan University of Medical Sciences, Kashan, IR, Iran.

Received: 12 October 2020 Accepted: 18 January 2021

Published online: 11 March 2021

\section{References}

1. Jameson JL, Kasper DL, Longo DL, Fauci AS, Hauser SL, Loscalzo J. Harrison's principles of internal medicine. 20th ed. New York: McGraw Hill Education; 2018.
2. Mazeh H, Orlev A, Mizrahi I, Gross DJ, Freund HR. Concurrent medullary, papillary, and follicular thyroid carcinomas and simultaneous Cushing's syndrome. Eur Thyroid J. 2015;4(1):65-8

3. Karakose M, Hasdemir O, Cakal E, Delibasi T. A rare coexistence of nonfunctional adrenocortical carcinoma and multicentric papillary thyroid microcarcinoma: a case report. J Med Case Rep. 2013;7:200.

4. Tung S-C, Wang P-W, Huang T-L, Yang JW, Chen W-J. Carney complex with primary pigmented nodular adrenocortical disease and bilateral papillary thyroid carcinoma occurring 11 years apart: a case report. Endocrinologist. 2005;15(4):243-7.

5. Esteghamati AR, Eshtiaghi R, Yousefizadeh AA, Nakhjavani M. Diagnosis and management of 253 cases with Cushing's syndrome in Imam Khomeini Hospital. Tehran Univ Med J. 2007;65(7):77-82.

\section{Publisher's Note}

Springer Nature remains neutral with regard to jurisdictional claims in published maps and institutional affiliations.
Ready to submit your research? Choose BMC and benefit from:

- fast, convenient online submission

- thorough peer review by experienced researchers in your field

- rapid publication on acceptance

- support for research data, including large and complex data types

- gold Open Access which fosters wider collaboration and increased citations

- maximum visibility for your research: over $100 \mathrm{M}$ website views per year

At BMC, research is always in progress.

Learn more biomedcentral.com/submissions 